\title{
Anti-Inflammatory Effect of Licochalcone E, a Constituent of Licorice, on Lipopolysaccharide-Induced Inflammatory Responses in Murine Macrophages
}

\author{
Geun-Mook Park', Jong-Gab Jun² and Jin-Kyung Kim* \\ ${ }^{1}$ Department of Biomedical Science, College of Natural Science, Catholic University of Daegu, Gyeoungsan-Si 700-712, Korea \\ ${ }^{2}$ Department of Chemistry and Institute of Natural Medicine, Hallym University, Chuncheon 200-702, Korea
}

Received March 3, 2011 / Accepted May 16, 2011

\begin{abstract}
Licochalcone, a major phenolic constituent of the licorice species Glycyrrhiza inflata, a constituent of licorice, exhibits various biological properties, including chemopreventive-, antibacterial-, and antispasmodic activities. Recently, Licochalcone E (LicE) was isolated from the roots of Glycyrrhiza inflate, however its biological functions have not been fully examined. In the present study, we investigated the ability of LicE to regulate inflammation reactions in macrophages. Our in vitro experiments using murine macrophages, RAW264.7 cells, showed that LicE suppressed not only nitric oxide (NO) and prostaglandin $\mathrm{E}_{2}$ generation, but also the expression of inducible NO synthase and cyclooxygenase-2 induced by lipopolysaccharide (LPS). Similarly, LicE inhibited the release of proinflammatory cytokines induced by LPS in RAW264.7 cells, including tumor necrosis factor-a and interleukin-6. The underlying mechanism of LicE on anti-inflammatory action correlated with down-regulation of the nuclear factor- $\mathrm{kB}$. Our data collectively indicate that LicE inhibited the production of several inflammatory mediators and might be used in the treatment of various inflammatory diseases.
\end{abstract}

Key words : Inflammation, licochalcone $\mathrm{E}, \mathrm{NF}-\kappa \mathrm{B}$, macrophage, inflammatory mediators

\section{Introduction}

Inflammation is part of complex biological responses to harmful stimuli, such as pathogens, damaged cells, or irritants. An inflammatory reaction is self-limiting and involves the down-regulation of proinflammatory protein expression and increased expression of anti-inflammatory proteins that facilitate the initial immune cell recruitment process $[5,22,23,29]$. During this response, inflammatory cells are exposed to apoptosis-inducing stimuli and subsequently undergo phagocytosis. Prolonged inflammation contributes to the pathogenesis of many inflammatory diseases [11,31].

The macrophage plays a critical role in the inflammatory response and serves as an essential interface between innate and adaptive immunity. Following activation, macrophages modulate the expression of accessory molecules, such as CD14 and Toll-like receptor (TLR) 4 [27,35]. Stimulation of TLR4 by lipopolysaccharide (LPS) in the presence of LPS-binding protein, CD14, and the MD2 protein triggers the recruitment of the cytoplasmic adaptor protein MyD88 and subsequently culminates in the activation of downstream signaling pathways, such as the transcription factor

*Corresponding author

Tel : +82-53-850-3774, Fax : +82-53-850-3774

E-mail : toto0818@cu.ac.kr nuclear factor- $\mathrm{kB}(\mathrm{NF}-\mathrm{\kappa} \mathrm{B})$ pathway [10]. This pathway induces the expression of various inflammatory mediators, including nitric oxide (NO), prostaglandins (PGs), and the inflammatory cytokines $[3,12,14,28]$.

$\mathrm{NF}-\kappa \mathrm{B}$, the key molecule in inflammatory responses, is a generic term for a dimeric transcription factor that is formed by the dimerization of proteins in the Rel family [8]. $\mathrm{NF}-\mathrm{\kappa B}$ activity is exerted through its ability to regulate the expression of genes that encode inflammatory cytokines, adhesion molecules, chemokines, growth factors, and inducible enzymes, such as cyclooxygenase (COX)-2 and inducible NO synthase (iNOS) [2].

PGs are produced by a variety of cell types, including the activated macrophage [19]. The rate-limiting enzyme in the synthesis of PGs is COX. Two main isoforms of COX have been described: COX-1 and COX-2. COX-1 is expressed constitutively in most tissues and is responsible for the homeostatic production of PGs. In contrast, COX-2 is induced by several stimuli, including growth factors, mitogens, cytokines, and tumor promoters. Its uncontrolled activity is thought to play an important role in the pathogenesis of many chronic inflammatory diseases [1,19]. In addition to PGs, NO is synthesized from l-arginine by NO synthases. Overproduction of NO by iNOS has been involved in the pathology of several inflammatory disorders, including sep- 
tic shock, tissue damage following inflammation [16,20,21]. Based on these observations, it has been hypothesized that the suppression of $\mathrm{NO}$ and PG production in macrophages could be key mechanisms to utilize in anti-inflammatory drug development.

Currently, a strong interest exists in developing new anti-inflammatory drugs from various natural products used in traditional medicine. Licorice has been used for more than four millennia as a flavoring agent in foods, beverages, and tobacco, as well as an alternative medicine to treat individuals with gastric or duodenal ulcers, sore throat, bronchitis, cough, arthritis, adrenal insufficiency, and allergies [34]. Among the constituents of licorice, licochalcone E (LicE) was isolated recently, however, its biological functions have yet to be fully tested [33]. Therefore, the anti-inflammatory effects of LicE were investigated using LPS-induced inflammatory response in the present study.

\section{Materials and Methods}

\section{Chemicals and reagents}

LPS derived from Escherichia coli and dimethylsulfoxide (DMSO) was obtained from Sigma (St Louis, Mo, USA). The Dulbecco's modified Eagle's medium (DMEM), fetal bovine serum (FBS), penicillin, and streptomycin used in this study were obtained from Hyclone (Logan, Utah, USA). Synthetic LicE (Fig. 1) was provided by Dr. Jong-Gab Jun [18]; it was dissolved in DMSO and added directly to the culture media. The final concentrations of DMSO never exceeded $0.1 \%$, which did not affect the assay systems. The antibodies (Abs) used in this study were: anti-iNOS rabbit polyclonal, anti-COX-2 mAb, anti-IkB mAb, anti-phospho-JNK (pT183, pY185) rabbit polyclonal, anti-ERK1/2 rabbit polyclonal, anti-phospho-p38 (pT180, pY182) rabbit polyclonal, anti-p38 rabbit polyclonal (Cell Signaling Technology, Danvers, MA), and anti- $\beta$-actin mAb (Sigma).

\section{Cell culture and cell viability assay}

RAW264.7 murine macrophages were obtained from the Korean Cell Bank (Seoul, Korea) and cultured in DMEM containing 10\% FBS, $100 \mathrm{U} / \mathrm{ml}$ penicillin, and $100 \mu \mathrm{g} / \mathrm{ml}$ streptomycin at $37^{\circ} \mathrm{C}$ in $5 \% \mathrm{CO}_{2}$. The effects of $\mathrm{LicE}$ on cell viability were tested using the CellTiter $96^{\circledR}$ AQueous One Solution Assay of cell proliferation (Promega, Madison, WI), which uses colorimetry to count the number of viable cells. RAW264.7 cells were plated at a density of $2 \times 10^{4}$ cells in

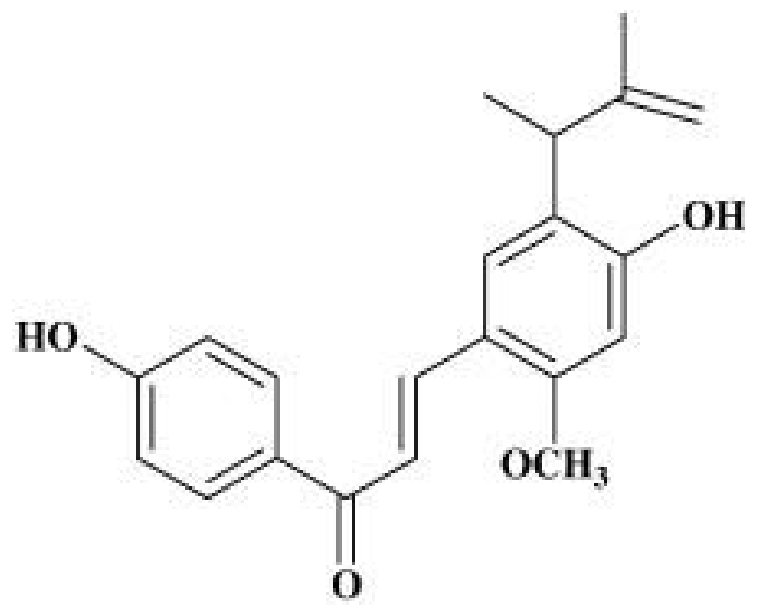

Fig. 1. Chemical structure of LicE.

a 96-well flat-bottom plate, and LicE were added to each plate at indicated concentrations. After a $24 \mathrm{hr}$ incubation period, the number of viable cells was counted according to the manufacturer's instructions. This assay is based on the reduction of a tetrazolium compound, MTS, to formazan, which has an optimum absorption at $490 \mathrm{~nm}$. Thus, the quantity of the product in the cell culture is indicated by the optical density of formazan at $490 \mathrm{~nm}$, which is directly proportional to the number of living cells.

\section{Measurement of nitrite and $\mathrm{PGE}_{2}$}

The amount of nitrite and $\mathrm{PGE}_{2}$ produced by the mouse macrophages was measured in the RAW264.7 cell culture supernatant. RAW264.7 cells were plated at a density of $2.5 \times 10^{5}$ cells in a 48 -well cell culture plate with $500 \mu \mathrm{l}$ of culture medium and incubated for $12 \mathrm{hr}$. They were then treated with indicated concentrations of LicE plus LPS (100 $\mathrm{ng} / \mathrm{ml}$ ) and incubated for another $18 \mathrm{hr}$. The amount of nitrite produced was measured using the Griess reagent system (Promega). The amount of $\mathrm{PGE}_{2}$ produced was measured using an enzyme-linked immunosorbent assay (ELISA) kit ( $R$ \& D, Minneapolis, MI) according to the manufacturer's instructions.

\section{Cytokine assays}

The amount of TNF- $\alpha$ and IL- 6 in the cell culture supernatant was measured using an ELISA kit (eBioscience, San Diego, CA). RAW264.7 cells were plated in a 48-well cell culture plate at a density of $2.5 \times 10^{5}$ cells and incubated with indicated concentrations of LicE in $100 \mathrm{ng} / \mathrm{ml}$ LPS for 24 hr. The culture supernatant was collected and assayed according to the manufacturer's instructions to determine the 
amount of TNF- $\alpha$ and IL- 6 that had been released from the cell.

\section{Immunoblotting analysis}

Whole cell extracts (30 $\mathrm{\mu g}$ protein/lane) were separated on $10 \%$ SDS-polyacrylamide gels. The separated proteins were electrophoretically transferred onto nitrocellulose membranes. Immunoreactive bands were detected by incubating the samples with horseradish peroxidase (HRP)conjugated secondary antibodies and WesternBreeze ${ }^{\circledR}$ Chromogenic Kits (Invitrogen, Carlsbad, CA).

\section{$\mathrm{NF}-\mathrm{\kappa B}$ activity}

RAW264.7 cells were placed in a 24-well cell culture plate at a density of $5 \times 10^{5}$ cells in $0.5 \mathrm{ml}$ of culture medium and incubated for $12 \mathrm{hr}$. The cells were then exposed to 0-20 $\mu \mathrm{M}$ LicE and LPS (100 ng/ml) for $4 \mathrm{hr}$. The transcriptional activities of NF- $\kappa \mathrm{B}$ were measured using TransAM (Active Motif, Carlsbad, CA), according to the manufacturer's instructions.

\section{Statistical analysis}

The data are depicted as the means $\pm S E$. The values were evaluated by one-way analysis of variance (ANOVA) with Bonferroni multiple comparison post tests using the GraphPad Prism 4.0 software (GraphPad Software Inc., San Diego, CA). Differences with $p<0.05$ were considered to be statistically significant.

$\mathbf{A}$

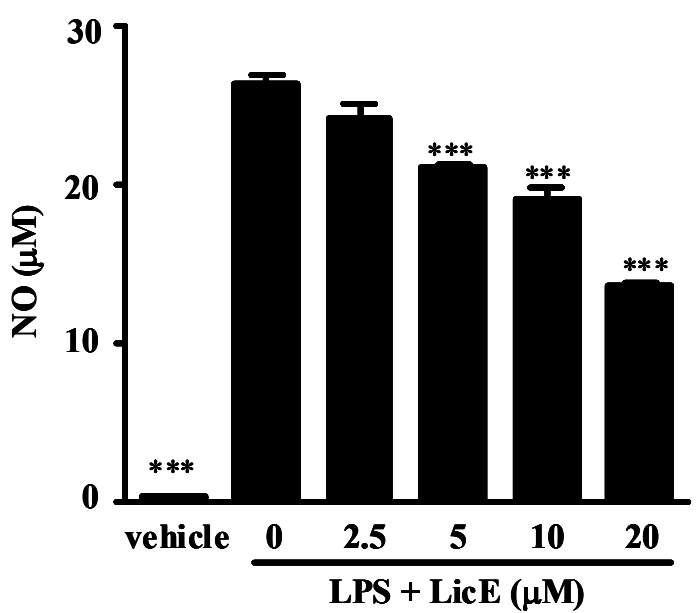

Results

\section{LicE inhibits the releases of $\mathrm{NO}$ and $\mathrm{PGE}_{2}$}

To evaluate LicE-induced anti-inflammatory effects, we used an in vitro model with the murine RAW264.7 macrophage cell line. Since LicE showed no cytotoxicity with concentrations up to $20 \mu \mathrm{M}$ in RAW264.7 macrophages (Fig. 2), we used up to $20 \mu \mathrm{M} \mathrm{LicE}$ for the rest of the experiments. We first sought to determine the effect of LicE on the

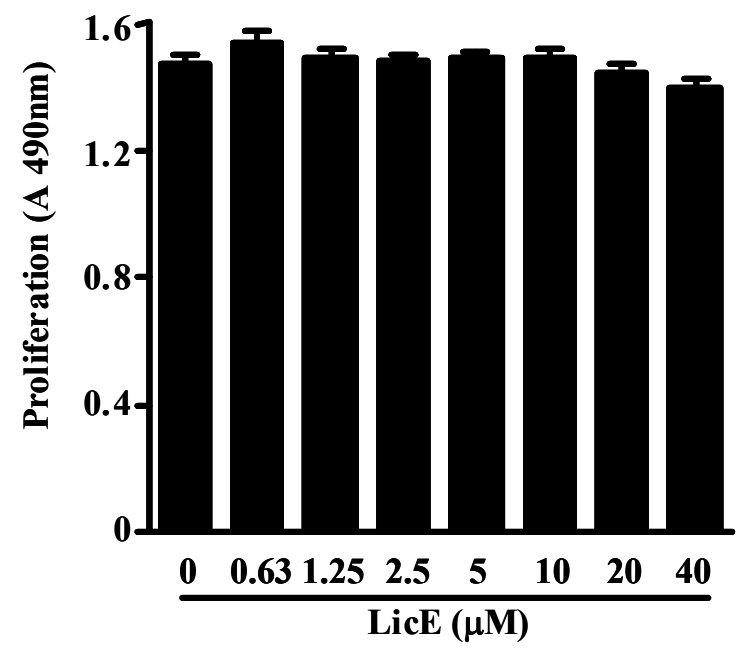

Fig. 2. Effects of LicE on murine macrophage viability. RAW264.7 cells were treated with indicated concentrations of LicE for $24 \mathrm{hr}$, and proliferation was determined as described in Materials and Methods.

B

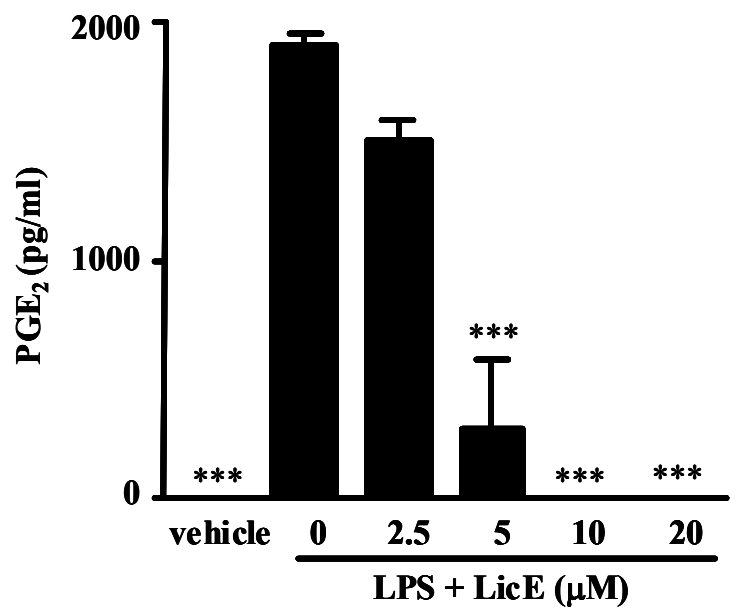

Fig. 3. Effects of LicE on LPS-induced NO and $\mathrm{PGE}_{2}$ release. RAW264.7 cells were treated with $0-20 \mu \mathrm{M}$ of LicE in the presence of $100 \mathrm{ng} / \mathrm{ml}$ of LPS or with LPS alone for $18 \mathrm{hr}$, and NO (A) and $\mathrm{PGE}_{2}$ (B) release were determined. The results are reported as mean $\pm \mathrm{SE}$ of four independent experiments in triplicate. Statistical significance is based on the difference when compared with LPS-stimulated cells $\left({ }^{\text {t*t }} p<0.001\right)$. 
LPS-stimulated release of the inflammatory mediators, NO and $\mathrm{PGE}_{2}$, by RAW264.7 cells. As shown in Fig. 3A, LicE inhibited LPS-induced $\mathrm{NO}$ and $\mathrm{PGE}_{2}$ production in a dose-dependent manner. The nitrite concentrations in LPS-stimulated cells and in those exposed to $20 \mu \mathrm{M} \mathrm{LicE}$ were $26.3 \pm 0.9 \mu \mathrm{M}$ and $13.5 \pm 0.5 \mu \mathrm{M}$, respectively. The inhibitory effects of LicE on $\mathrm{PGE}_{2}$ production in LPS-exposed cells were similar to their effects on $\mathrm{NO}$ production (Fig. 3B). Consistent with the findings related to $\mathrm{NO}$ and $\mathrm{PGE}_{2}$ production, immunoblotting analysis showed that LPS-related iNOS and COX-2 induction in RAW264.7 cells was also reduced by LicE treatment (Fig. 4). This indicates that the LicE-induced reduction in iNOS and COX-2 expression was responsible for the inhibition of $\mathrm{NO}$ and $\mathrm{PGE}_{2}$ production.

LicE inhibits the release of proinflammatory cytokines

We next examined if LicE reduced the release of proinflammatory cytokines in LPS-stimulated RAW264.7 cells. The release of TNF- $\alpha$ and IL- 6 was significantly impaired by LicE co-treatment of LPS-exposed cells (Fig. 5). These results indicate that LicE suppressed various inflammatory mediators including $\mathrm{NO}$ and $\mathrm{PGE}_{2}$, as well as proinflammatory cytokines.

A

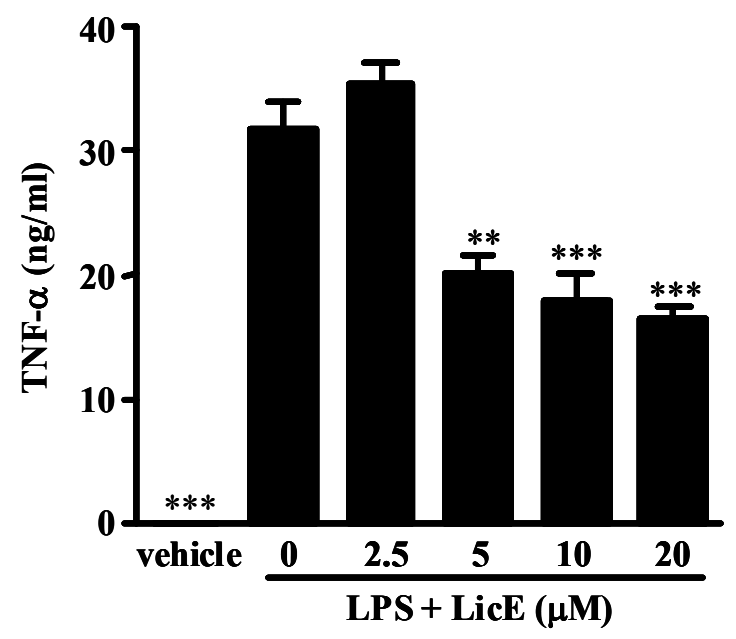

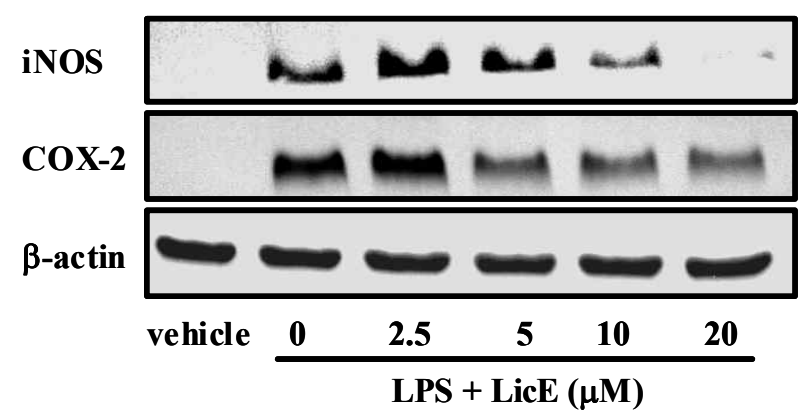

Fig. 4. Effects of LicE on LPS-induced iNOS and COX-2 expression. RAW264.7 cells treated the same as in Fig. 2. Thirty $\mu \mathrm{g}$ of protein obtained from each cell lysate was resolved on 10\% SDS-PAGE for iNOS and COX-2 determination. $\beta$-actin expression is shown as a loading control.

LicE-reduced inflammatory mediator release is regulated by $\mathrm{NF}-\kappa \mathrm{B}$

We further investigated the mechanism by which LicE inhibited the production of inflammatory mediators. NF- $\mathrm{kB}$ is a major transcription factor involved in the release of proteins that mediate the inflammatory response, and the degradation and phosphorylation of inhibitor of $\kappa \mathrm{B}$ (Iк-B) are necessary to release NF- $\kappa \mathrm{B}$ from the cytoplasmic NF- $\kappa \mathrm{B} / \mathrm{I} \kappa-\mathrm{Ba}$ complex and allow its subsequent translocation to the cell nucleus. We evaluated the effect of LicE on NF- $\mathrm{B}$ activation to determine if it is mediated by IK-B degradation. We found

B

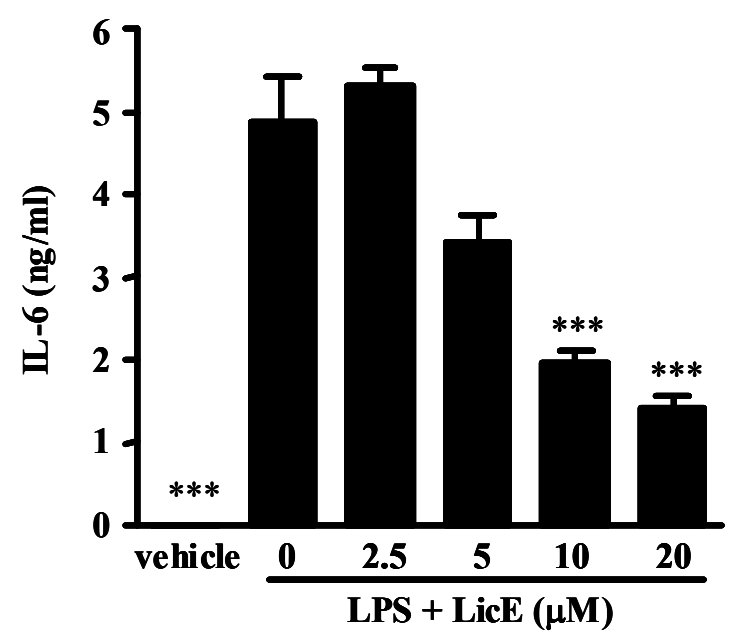

Fig. 5. Effects of LicE on LPS-induced inflammatory cytokine production in murine macrophages. RAW264.7 cells were treated with $0-20 \mu \mathrm{M}$ of LicE in the presence of $100 \mathrm{ng} / \mathrm{ml}$ LPS or with LPS alone for $24 \mathrm{hr}$. The cell culture media were then collected, and the amount of TNF- $\alpha$ (A) and IL-6 (B) released was measured as described in Materials and Methods. The results are reported as mean $\pm \mathrm{SE}$ of three independent experiments in triplicate. Statistical significance is based on the difference when compared with LPS-stimulated cells $\left({ }^{* * *} p<0.01, \quad{ }^{* n *} p<0.01\right)$. 
A

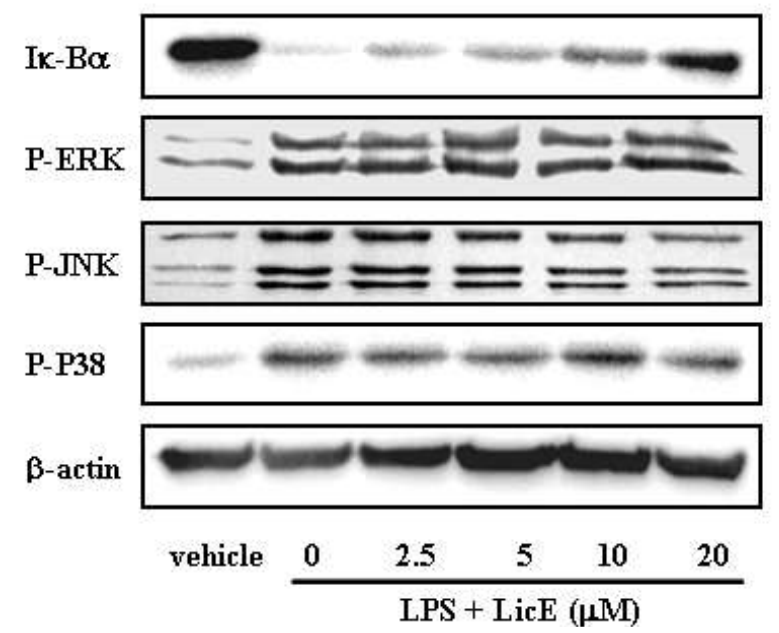

B

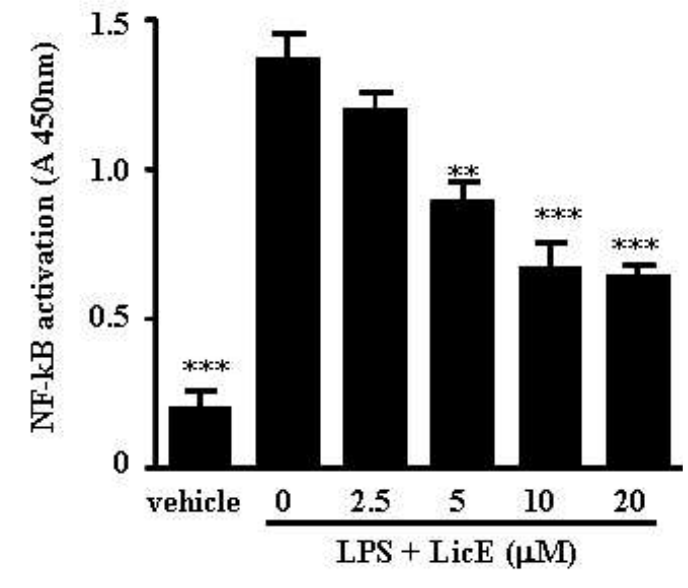

Fig. 6. Effect of LicE on LPS-induced Ik-B degradation and DNA-binding of NF- $\kappa$ B in LPS-stimulated murine macrophages. (A) RAW264.7 cells were plated in 100-mm dishes. After $12 \mathrm{hr}$ of seeding, cells were treated with different doses of LicE for $1 \mathrm{hr}$, followed by stimulation with $100 \mathrm{ng} / \mathrm{ml}$ of LPS for $20 \mathrm{~min}$. Whole cell extracts were immunoblotted with the indicated Abs. $\beta$-actin was used as a control. (B) RAW264.7 cells were treated with various concentrations of LicE in the presence of $100 \mathrm{ng} / \mathrm{ml}$ LPS or with LPS alone for $4 \mathrm{hr}$. After nuclear protein extraction, $2 \mu \mathrm{g}$ of nuclear protein were assayed for the ability to bind to the immobilized NF- $\mathrm{kB}$ consensus site as described in Materials and Methods. The results are reported as mean \pm SE of three independent experiments in triplicate. Statistical significance is based on the difference when compared with LPS-stimulated cells $\left(p<0.01,{ }^{* * * *} p<0.001\right)$.

that LPS-induced Ik-B degradation was inhibited after $20 \mathrm{mi}-$ nutes of exposure to LicE (Fig. 6A).

LPS activates not only NF- $\kappa \mathrm{B}$, but also MAPK family members such as ERK, p38, and JNK, and it plays a crucial role in mediating the induction of proinflammatory cytokines. We sought to determine if LicE modulated the MAPK signal transduction pathway. As shown in Fig. 5A, the activation of ERK, JNK, and p38 via LPS stimulation in RAW264.7 cells was not altered by LicE.

To directly observe the effect of LicE on the nuclear translocation and DNA binding of NF- $\kappa \mathrm{B}$, we performed a transcription factor ELISA assay. We found that LPS-induced DNA-binding of NF- $\mathrm{B}$ was significantly inhibited in LPS-stimulated RAW264.7 cells exposed to LicE in a dose-dependent manner (Fig. 6B).

\section{Discussion}

Numerous studies have focused on herbal remedies and botanicals since they offer much promise in health benefits and disease treatments without excessive side effects and cytotoxicity [17]. A wide variety of plant-derived products have shown an anti-inflammatory effect, but only a few have been examined to determine the molecular mechanism of this inhibitory action. It has been reported that licorice is one of the most common plants prescribed by practitioners of traditional alternative medicine $[12,16,21]$. Indeed, our previous study demonstrated that ethanol extracts of licorice exert suppressive effects on LPS-induced inflammatory reactions [20]. Moreover, glabridin, a major component of the hydrophobic fraction of licorice, has preventive and therapeutic effects on DSS-induced colonic inflammation [21]. The focus of this report is on the anti-inflammatory potency of LicE, the characteristic phenolic constituent of licorice $[3,27]$.

In this study, we investigated the anti-inflammatory properties of LicE and dissected its possible molecular mechanism of action. The results presented herein showed that LicE significantly decreased $\mathrm{NO}$ and $\mathrm{PGE}_{2}$ production in LPS-stimulated murine macrophages. The inhibition of NO and $\mathrm{PGE}_{2}$ was due to the inhibition of iNOS and COX-2 expression, respectively, at protein levels as shown by immunoblot. Moreover, we demonstrated that LicE suppressed iNOS and COX-2 expression as well as the release of proinflammatory cytokines, possibly via the inhibition of LPS-induced NF- $\kappa B$ activation. Several recent studies re- 
ported that reduced NF- $\kappa$ B activation by LicE induces apoptosis in endothelial cells [7] and inhibits the symptoms of chronic contact dermatitis in mice [9]. Although the exact mechanisms by which LicE inhibits NF- $\mathrm{kB}$ activation are not known, one possible explanation is that reduction of $\mathrm{NO}$, a reactive oxygen species, by LicE may be involved in NF- $\kappa \mathrm{B}$ inactivation because licochalcones are known to be reactive oxygen scavengers [16].

Accumulated evidence indicates that dysregulation of cytokines, such as TNF- $\alpha$ and IL-6, plays an essential role in many inflammatory conditions like septic shock, hemorrhagic shock, rheumatoid arthritis, and atherosclerosis $[13,25]$. Inhibition of inflammatory cytokine and mediator production or function serves as a key mechanism in the control of inflammation, and agents that suppress the expression of these inflammation-associated genes have therapeutic potential in the treatment of inflammatory diseases. Therefore, natural phytochemicals have attracted clinical interest as potential therapeutic agents for the treatment of inflammation. In addition to proinflammatory cytokines, COX-2 is an essential molecule to regulate inflammatory responses. The PG production in LPS-treated macrophages is primarily due to transcriptional activation of the COX-2 gene [24]. Thus, potential COX-2 inhibitors have been considered as anti-inflammatory agents.

Expression of iNOS, COX-2, TNF- $\alpha$, and IL-6 requires the activation of NF- $\kappa \mathrm{B}$, which is an important proximal mechanism for the overproduction of the inflammatory mediators in macrophages in response to LPS and cytokines [26]. Meanwhile, NF- $\kappa B$ plays a critical role in apoptosis, various autoimmune diseases and inflammation [2,15]. Recently, many investigations demonstrated that many anti-inflammatory drugs including dexamethasone can inhibit the production of IL-1 $\beta$, TNF- $\alpha$, and NO by suppression of NF$\mathrm{\kappa B}$ activation [32]. Due to its ubiquitous role in the pathogenesis of inflammatory gene expression, NF- $\kappa \mathrm{B}$ is a current target for treating various inflammation diseases [30]. Since multiple studies have demonstrated the importance of these inflammation factors in the inflammation process, the anti-inflammatory action of several drugs at the cellular level could be explained by their effects on these factors. Hence we studied these key inflammation cytokines and mediators in LPS-stimulated RAW 264.7 cells to elucidate the anti-inflammatory effects of LicE.

In conclusion, our observations suggest that LicE strongly inhibits the production of inflammation-associated media- tors by suppressing NF- $\kappa \mathrm{B}$ activation, and therefore, LicE may be a potential candidate for treating various inflammatory diseases.

\section{Acknowledgement}

This research was supported by Basic Science Research Program through the National Research Foundation of Korea (NRF) funded by the Ministry of Education, Science and Technology (2010-0004728) and Priority Research Centers Program through the National Research Foundation of Korea (NRF) funded by the Ministry of Education, Science and Technology (2010-0029642).

\section{References}

1. Aktan, F. 2004. iNOS-mediated nitric oxide production and its regulation. Life Sci. 75, 639-653.

2. Baker, R. G., M. S. Hayden, and S. Ghosh. 2011. NF-kB, inflammation, and metabolic disease. Cell Metab. 13, 11-22.

3. Barfod, L., K. Kemp, M. Hansen, and A. Kharazmi. 2002. Chalcones from chinese liquorice inhibit proliferation of $\mathrm{T}$ cells and production of cytokines. Int. Immunopharmacol. 2, 545-555.

4. Bielory, L. 2004. Complementary and alternative interventions in asthma, allergy, and immunology. Ann. Allergy Asthma Immunol. 93, S45-54.

5. Blackwell, T. S. and J. W. Christman. 1997. The role of nuclear factor-kappa B in cytokine gene regulation. Am J. Respir. Cell Mol. Biol. 7, 3-9.

6. Carbonell-Barrachina, A. A., P. Aracil, E. Garcia, F. Burlo, and F. Martinez-Sanchez. 2003. Source of arsenic in licorice confectionery products. J. Agric. Food Chem 51, 1749-1752.

7. Chang, H. J., G. Yoon, J. S. Park, M. H. Kim, M. K. Baek, N. H. Kim, B. A. Shin, B. W. Ahn, S. H. Cheon, and Y. D. Jung. 2007. Induction of apoptosis by the licochalcone $E$ in endothelial cells via modulation of NF-kappaB and Bcl-2 Family. Biol. Pharm Bull. 30, 2290-2293.

8. Cho, M. K., S. H. Suh, and S. G. Kim. 2002. JunB/AP-1 and NF-kappa B-mediated induction of nitric oxide synthase by bovine type I collagen in serum-stimulated murine macrophages. Nitric Oxide 6, 319-332.

9. Cho, Y. C., S. H. Lee, G. Yoon, H. S. Kim, J. Y. Na, H. J. Choi, C. W. Cho, S. H. Cheon, and B. Y. Kang. 2010. Licochalcone E reduces chronic allergic contact dermatitis and inhibits IL-12p40 production through down-regulation of NF-kappa B. Int. Immunopharmacol. 10, 1119-26.

10. Fu, Y. T., C. Hsieh, J. Guo, J. Kunicki, M. Y. Lee, Z. Darzynkiewicz, and J. M. Wu. 2004. Licochalcone-A, a novel flavonoid isolated from licorice root (Glycyrrhiza glabra), causes G2 and late-G1 arrests in androgen-independent PC-3 prostate cancer cells. Biochem Biophys. Res. Commun. 
322, 263-270.

11. Fukai, T., A. Marumo, K. Kaitou, T. Kanda, S. Terada, and T. Nomura. 2002. Anti-Helicobacter pylori flavonoids from licorice extract. Life Sci. 71, 1449-1463.

12. Fukai, T., K. Satoh, T. Nomura, and H. Sakagami. 2003. Preliminary evaluation of antinephritis and radical scavenging activities of glabridin from Glycyrrhiza inflate. Fitoterapia 74, 624-629.

13. Ghezzi, P. and A. Cerami. 2005. Tumor necrosis factor as a pharmacological target. Mol. Biotechnol. 31, 239-244.

14. Guha, M. and N. Mackman. 2001. LPS induction of gene expression in human monocytes. Cell Signal. 13, 85-94.

15. Gyrd-Hansen, M. and P. Meier. 2010. IAPs: from caspase inhibitors to modulators of NF-kappaB, inflammation and cancer. Nat. Rev. Cancer 10, 561-74.

16. Haraguchi, H., H. Ishikawa, K. Mizutani, Y. Tamura, and T. Kinoshita. 1998. Antioxidative and superoxide scavenging activities of retrochalcones in Glycyrrhiza inflata. Bioorg. Med Chem 6, 339-347.

17. Jachak, S. M. and A. Saklani. 2007. Challenges and opportunities in drug discovery from plant. Curr. Sci. 92, 1251-1257.

18. Jeon, J. H., M. R. Kim, E. M. Kwon, N. R. Lee, and J. G. Jun. 2011. Highly efficient synthesis of licochalcone $E$ through water-accelerated [3,3]-sigmatropic rearrangement of allyl aryl ether. Bull. Korean Chem Soc. 32, 1059-1062.

19. Kamimura, D., K. Ishihara, and T. Hirano. 2003. IL-6 signal transduction and its physiological roles: the signal orchestration model. Rev. Physiol. Biochem Pharmacol. 149, 1-38.

20. Kim, J. K., S. M. Oh, H. S. Kwon, Y. S. Oh, S. S. Lim, and H. K. Shin. 2006. Anti-inflammatory effect of roasted licorice extracts on lipopolysaccharide-induced inflammatory responses in murine macrophages. Biochem Biophys. Res. Commun. 345, 1215-1223.

21. Kwon, H. S., S. M. Oh, and J. K. Kim. 2008. Glabridin, a functional compound of liquorice, attenuates colonic inflammation in mice with dextran sulphate sodium-induced colitis. Clin. Exp. Immunol. 151, 165-173.

22. Lang, R. M., M. Hammer, and J. Mages. 2006. DUSP meet immunology: dual specificity MAPK phosphatases in control of the inflammatory response. J. Immunol. 177, 7497-7504.

23. Lawrence, T. D., A. Willoughby, and D. W. Gilroy. 2002. Anti-inflammatory lipid mediators and insights into the resolution of inflammation. Nat. Rev. Immunol. 2, 787-795.
24. Lo, C. J., M. Fu, F. R. Lo, and H. G. Cryer. 2000. Cyclooxygenase 2 (COX-2) gene activation is regulated by cyclic adenosine monophosphate. Shock 13, 41-45.

25. Montecucco, F. and F. Mach. 2009. Common inflammatory mediators orchestrate pathophysiological processes in rheumatoid arthritis and atherosclerosis. Rheumatology 48, 11-22.

26. Müller, J. M., H. W. Ziegler-Heitbrock, and P. A. Baeuerle. 1993. Nuclear factor kappa B, a mediator of lipopolysaccharide effects. Immunobiology 187, 233-56.

27. Nielsen, S. F., T. Boesen, M. Larsen, K. Schonning, and H. Kromann. 2004. Antibacterial chalcones-bioisosteric replacement of the 4 ' -hydroxy group. Bioorg. Med Chem 12, 3047-3054.

28. Ohsawa, M., T. Koyama, N. Nara, and S. Hirosawa. 2003. Induction of tissue factor expression in human monocytic cells by protease inhibitors through activating activator protein-1 (AP-1) with phosphorylation of Jun-N-terminal kinase and p38. Throm Res. 112, 313-320.

29. O'Shea, J. J. and P. J. Murray. 2008. Cytokine signaling modules in inflammatory responses. Immunity 28, 477-487.

30. Renard, P. and M. Raes. 1999. The proinflammatory transcription factor NFkappaB: a potential target for novel therapeutical strategies. Cell Biol. Toxicol. 15, 341-3444.

31. Tominaga, K., S. Saito, M. Matsuura, and M. Nakano. 1999. Lipopolysaccharide tolerance in murine peritoneal macrophages induces downregulation of the lipopolysaccharide signal transduction pathway through mitogen-activated protein kinase and nuclear factor-kappaB cascades, but not lipopolysaccharide-incorporation steps. Biochim Biophys. Acta. 1450, 130-144.

32. Yamamoto, Y. and R. B. Gaynor. 2001. Role of the NF-kappaB pathway in the pathogenesis of human disease states. Curr. Mol. Med 1, 287-296.

33. Yoon, G., Y. D. Jung, and S. H. Cheon. 2005. Cytotoxic allyl retrochalcone from the roots of Glycyrrhiza inflata. Chem Pharm Bull. 53, 694-695.

34. Zhou, S., H. L. Koh, Y. Gao, Z. Y. Gong, and E. J. Lee. 2004. Herbal bioactivation: the good, the bad and the ugly. Life Sci. 74, 935-968.

35. Ziegler, H. L., H. S. Hansen, D. Staerk, S. B. Christensen, H. Hagerstrand, and J. W. Jaroszewski. 2004. The antiparasitic compound licochalcone A is a potent echinocytogenic agent that modifies the erythrocyte membrane in the concentration range where antiplasmodial activity is observed. Antimicrob. Agents. Chemother. 48, 4067-4071. 


\section{초록 : Licochalcone E의 항염증 효과와 그 기전에 대한 연구}

박근묵 $\cdot$ 전종갑 ${ }^{2} \cdot$ 김진경 ${ }^{1}$ *

(대구가톨릭대학교 의생명과학과, ${ }^{2}$ 한림대학교 화학과)

Licochalcone은 감초의 주요 생리활성 물질로 항균작용, 항암작용 등의 다양한 효과가 있는 것으로 알려져 있 다. 최근 감초로부터 licochalcone E가 분리, 동정 되었을 뿐만 아니라, 효과적인 licochalcone $\mathrm{E}$ 의 합성을 위해 다양한 합성법이 개발되고 있다. 반면, licochalcone E의 생리활성 연구는 매우 미비한 상태이다. 본 연구는 licochclcone E의 항염증 활성과 그 기전의 일단을 밝히는 것을 목적으로 진행 되었다. 생쥐의 대식세포주인 RAW264.7 세포에 lipopolysaccharide (LPS)를 처리 염증반응을 유도하고, licochalcone E를 처리한 한 결과, licochalcone E는 LPS 처리에 의한 nitric oxide $(\mathrm{NO})$, prostaglandin $\mathrm{E}_{2}\left(\mathrm{PGE}_{2}\right)$ 및 염증성 사이토카인의 분비를 현저히 억제시키는 것을 관찰 할 수 있었으며, $\mathrm{NO}$ 와 $\mathrm{PGE}_{2}$ 생합성효소인 $\mathrm{iNOS}$ 와 COX-2 단백질의 발현 또한 억제시킴을 확인할 수 있었다. 이러한 licochalcone $\mathrm{E}$ 의 항염증 활성의 기전을 밝히기 위해 염증반응에 핵심적인 역할을 하는 전사인자인 nuclear factor-kB (NF-kB)의 활성을 관찰한 결과, licochalcone E의 처리가 NF-kB의 DNA결합을 억제하는 것을 확인 하였다. 이러한 연구결과로 볼 때 licochalcone E가 NF-kB의 활성을 억제하여, 염증반응의 매개물질인 $\mathrm{NO}, \mathrm{PGE}_{2}$, 염증성 사이토카인 등의 생성을 억제함으로 항염증활성을 나타내는 것으로 판단된다. 